\title{
Capillary Electrophoresis with Laser-Induced Fluorescence Detection as a Tool for Enzyme Characterization and Inhibitor Screening
}

\author{
Dan-Ning LIU,* Li LI,** Wei-Ping Lu,** Yao-Qing D. LIU,** Ken R. WeHMEYER,** and \\ James J. BAO*ं \\ * School of Pharmaceutical Science and Technology, Tianjin University, Tianjin 300072, China \\ **Procter \& Gamble Pharmaceuticals, 8700 Mason-Montgomery Road, Mason, OH 45040, USA
}

\begin{abstract}
An effective, rapid and economical CE/LIF (capillary electrophoresis/laser-induced fluorescence) method was developed and applied to the characterization of signal peptidase (SPase) enzyme, which is a target for the screening of new drug candidates. In this method, CE separates the product from the substrate and LIF selectively detects the fluorescencelabeled product and substrate. By measuring the increase of the product as a function of time, one can monitor the progression of the enzyme reaction. The progression curves were also used for screening inhibitors for this enzyme. The effects of various reaction conditions were also studied and discussed. In addition, this CE/LIF method was applied to the determination of the enzyme activity, the quality control of the substrate and/or enzymes, and the cross-reactivity of inhibitors to the enzyme. It can be concluded that this method is suitable for high throughput screening (HTS) assays because it can deliver fast, sensitive, quantitative, and reliable results.
\end{abstract}

(Received April 2, 2007; Accepted May 25, 2007; Published March 10, 2008)

\section{Introduction}

Signal peptidases (SPases) play an essential role in the protein secretary pathway of prokaryotic organisms..$^{1-3}$ They catalyze the release of the signal peptide from the nature portion of a secreted protein, which facilitates protein translation across the membrane. ${ }^{4-6}$ Since the above procedure is related with some infectious diseases, signal peptidases have been regarded as an attractive target for design of novel antibacterial compounds. ${ }^{7}$ For this purpose, researchers have hypothesized that a compound may be developed into an anti-infective drug if it inhibits this enzyme. ${ }^{8}$ Meanwhile, the ability to screen for and characterize inhibitors of signal peptidases would represent a significant advance for the discovery of antibacterial agents in the pharmaceutical industry. ${ }^{9}$ In recent years, considerable progress has been made in the characterization and inhibition of the enzyme, including identification of active sites, ${ }^{10-12}$ characterization of catalytic mechanisms, ${ }^{13,14}$ and improvement of substrates. ${ }^{15,16}$ In inhibition studies ${ }^{9,17}$ of signal peptidases, a routine analytical method, fluorescence polarization (FP) method, can be adopted to measure the reaction product. However, it has been reported that FP is generally not a good method for enzyme characterization except for those enzymes that have $K_{\mathrm{m}}$ values below $10 \mu \mathrm{mol} / \mathrm{L} .^{18}$ The FP signal increases with molecular weight, so the smaller peptide will have less FP signal. Thus, the kinetic parameters can not be accurately determined by FP method. As a separation-based method, application of HPLC method was also reported. ${ }^{19}$ But the large sample consumption and troublesome treatment of

$\dagger$ To whom correspondence should be addressed.

E-mail: Bao@tju.edu.cn organic reagents post-experiment are factors that should be considered.

$\mathrm{CE}$ is widely perceived as a fast, economical, and efficient separation technique; when used in combination with LIF, it also has high sensitivity. ${ }^{20-23}$ Our goal of this study is to present and evaluate a robust CE/LIF method for characterizing SPases and their interactions with potential inhibitors. The substrate of SPase used in this study was a synthesized fluorescence-labeled proprietary peptide $(20 \mathrm{kDa})$ found in the literature. ${ }^{16}$ After reacting with SPase, the substrate was cut into a smaller product peptide $(2 \mathrm{kDa})$ with the fluorescent tag and the larger peptide without fluorescence. Based on the difference of electrophoretic mobility of detectable substrate and product, they are easily separated. This robust CE/LIF method is thus propitious to characterize SPases and their interactions with potential inhibitors. In this article, this CE/LIF method has been used to perform various projects, such as study of enzyme kinetics, screening of enzyme inhibitors and quality control of the enzyme/substrate. In addition, the reaction conditions, such as $\mathrm{pH}$, dimethyl sulfoxide (DMSO), urea concentration, and incubation time, were also studied and are discussed.

\section{Experimental}

\section{Reagents and chemicals}

All samples and buffers were prepared with analytical reagent grade chemicals and deionized water from a Milli-Q Plus system (Millipore Corp., Milford, MA). The product fluorescent peptide ( $2 \mathrm{kDa}$ ) was custom-synthesized as an assay standard. Fluorescein-5-maleimide (F-5-M) was purchased from PIERCE (Rockford, IL). Boric acid and Trizma crystal pre-set at pH 8.0 were purchased from Sigma (St. Louis, MO). 
All solutions were degassed in an ultrasonic bath for $5 \mathrm{~min}$ and filtered through a $0.22-\mu \mathrm{m}$ syringe filter (Ann Arbor, MI) prior to use.

The enzyme sample, a proprietary fluorescent-labeled substrate, and inhibitors were obtained from the anti-infective research project team at Procter \& Gamble Pharmaceuticals.

Trizma $(50 \mathrm{mmol} / \mathrm{L})$ was prepared by dissolving Trizma crystal pre-set at $\mathrm{pH} 8.0$ in water, and $50 \mathrm{mmol} / \mathrm{L}$ borate buffer was made with boric acid and titrated to $\mathrm{pH} 10.5$ with $1.0 \mathrm{~mol} / \mathrm{L}$ $\mathrm{NaOH}$. Substrate working solutions at different concentrations were prepared by diluting the provided stock solution (86 $\mathrm{mmol} / \mathrm{L}$ ) with $50 \mathrm{mmol} / \mathrm{L}$ Trizma, $\mathrm{pH} \mathrm{7.2,} 6.0 \mathrm{~mol} / \mathrm{L}$ urea, and $1.0 \mathrm{mmol} / \mathrm{L}$ EDTA. Both the enzyme and substrate were aliquoted to small volumes and stored at $-70^{\circ} \mathrm{C}$ before use.

The inhibitor working solutions were prepared by diluting the stock solution with $50 \mathrm{mmol} / \mathrm{L}$ Trizma at $\mathrm{pH} 8.0$ to the final concentration of DMSO at $1.0 \%(\mathrm{v} / \mathrm{v})$.

All the calibration standards were prepared by diluting this stock solution with the matrix used for the kinetic reaction.

The enzyme and substrate were taken out from the $-70^{\circ} \mathrm{C}$ freezer and thawed at room temperature for $10-15$ min prior to use. Then both the enzyme and substrate were diluted with $50 \mathrm{mmol} / \mathrm{L}$ Trizma to the expected concentrations. For kinetic study, a series of $10 \mu \mathrm{L}$ of substrate at varying concentrations and $80 \mu \mathrm{L}$ of $50 \mathrm{mmol} / \mathrm{L}$ Trizma, $\mathrm{pH} 8.0$ were mixed first. Then, $10 \mu \mathrm{L}$ of enzyme was added to the mixture; the final volume for each reaction was $100 \mu \mathrm{L}$. The contents were gently mixed with a vertex to start the reaction. For inhibitor screening study, $40 \mu \mathrm{L}$ of each inhibitor and 5.0 $\mu \mathrm{L}$ of enzyme were mixed first for $5 \mathrm{~min}$ at room temperature. Then $5.0 \mu \mathrm{L}$ of substrate was added to the mixture so the final volume is $100 \mu \mathrm{L}$, and the contents were gently mixed with a vertex to start the reaction.

\section{Apparatus}

All the CE experiments were performed on a Beckman (Fullerton, CA) P/ACE $5000 \mathrm{CE}$ system equipped with a LIF detector (Laser module 488). Samples were injected from the anode side and detected on the cathode side (normal polarity). The separation was carried out by applying a $20 \mathrm{kV}$ potential difference on a total length of $27 \mathrm{~cm}$ and an i.d. of $50 \mu \mathrm{m}$ uncoated fused silica capillary (Polymicro Technologies Inc., Phoenix, AZ) with an effective length of $20 \mathrm{~cm}$ to the detection window. LIF detection was done with the excitation wavelength at $488 \mathrm{~nm}$ and the emission wavelength at $520 \mathrm{~nm}$ for selective detection of generated fluorescence. The electropherograms were obtained by using the Beckman P/ACE Station software. The temperature of the capillary was controlled at $24^{\circ} \mathrm{C}$ while the temperature of samples was at ambient. The injection time was $10 \mathrm{~s}$ at a pressure of 0.5 psi. The running buffer was $50 \mathrm{mmol} / \mathrm{L}$ borate buffer at $\mathrm{pH} 10.5$. The capillary was washed between runs for 0.3 min with 0.1 $\mathrm{mol} / \mathrm{L} \mathrm{NaOH}$ followed by $0.3 \mathrm{~min}$ of running buffer using a high pressure of 20 psi.

The experiments of confirmation of peptide and reaction product were performed on a Finnigan LC/ESI/MS ${ }^{n}$ system consisting of a Surveyor HPLC with quaternary gradient pumps and an autosampler coupled with a Finnigan LCQ Advantage ion-trap mass spectrometer (Thermo Electron, San Jose, CA). The substrate and product were processed through a C18 column $(150 \times 2.1 \mathrm{~mm}, 5 \mu \mathrm{m})$ without additional purification. The online MS analyses were carried out in negative ESI ionization mode. Spray voltage was $5.0 \mathrm{kV}$ and ion transfer capillary temperature was $300^{\circ} \mathrm{C}$. Nitrogen was used as sheath and auxiliary gases with flow rates set at 35 and 5 units, respectively.

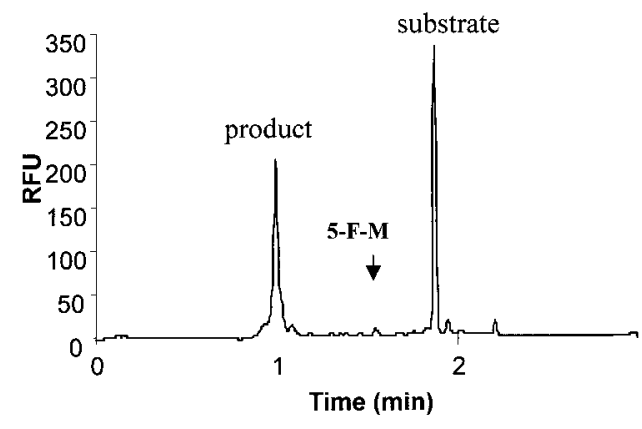

Fig. 1 Separation of the mixture of $2 \mathrm{kDa}$ peptide from the $20 \mathrm{kDa}$ peptide substrate. Experimental conditions: $20 \mathrm{kV}, 27 \mathrm{~cm}(20 \mathrm{~cm}$ effective separation length $) \times 50 \mathrm{~mm}$ i.d. (351 mm o.d.) uncoated fused silica capillary, $488 \mathrm{~nm}$ excitation, $520 \mathrm{~nm}$ emission, capillary at $24^{\circ} \mathrm{C}$ and the samples at ambient, $10 \mathrm{~s}$ injection time. The running buffer: $50 \mathrm{mmol} / \mathrm{L}$ borate buffer at $\mathrm{pH} 10.5$. The capillary was washed between runs for $0.3 \mathrm{~min}$ with $0.1 \mathrm{M} \mathrm{NaOH}$ followed by 0.3 min of running buffer.

Table 1 Molecular weight determination of product and substrate of SPases by CE/MS

\begin{tabular}{clccc}
\hline $\begin{array}{c}\text { Sample } \\
\text { No. }\end{array}$ & Peptide & $\begin{array}{c}\text { Calculated } \\
\text { Mr value }\end{array}$ & $\begin{array}{c}\text { Migration } \\
\text { time/min }\end{array}$ & $\begin{array}{r}\text { Determined } \\
\text { Mr value }\end{array}$ \\
\hline \multirow{2}{*}{1} & Substrate & 19470.2 & 1.85 & 19470.8 \\
& Product & 2658.9 & 0.92 & 2676.6 \\
2 & Syn. peptide & 2658.9 & 0.92 & 2676.6 \\
\hline
\end{tabular}

The synthetic peptide was ordered based on the expected sequence.

\section{Results and Discussion}

\section{Effect of $p H$ on enzyme activity}

The enzyme activity is highly dependent on the electrolyte pH. To evaluate the preferred $\mathrm{pH}$, we kept all reaction conditions the same except the $\mathrm{pH}$, which we varied. Within the uniform reaction time, more product was generated in the $\mathrm{pH}$ range of $7.5-8.5$. It is clear that the SPase enzyme is most active in this range. Therefore, the electrolyte $\mathrm{pH}$ was fixed at 8.0 to optimize other parameters.

\section{Separation and quantitation of the product}

CE can quickly separate the peptide product from the substrate (Fig. 1). The other product, a peptide $(18 \mathrm{kDa})$, was not detected because it was not fluorescent. The free fluorescent tag, F-5-M, was also separated from both the substrate and the product. F-5-M migrated right in the middle of the substrate and the product and would not affect the detection of either the product or the substrate. Since the substrate was almost F-5-M free, there was no F-5-M peak in most of the electropherograms. This separation was done at a relatively high $\mathrm{pH}$ (10.5) because we wanted to develop a method that could finish the run in a relatively short period of time. Figure 1 indicates that the product $(2 \mathrm{kDa})$ peak came out in less than $1 \mathrm{~min}$. It was ideal for continuous injection with short interval, as required in the enzyme kinetics study.

In order to confirm the structure of the detected peptide product, we had a pure fluorescent-labeled peptide having the same expected sequence synthesized. This synthesized standard along with the substrate and the product of the reaction were analyzed by both CE/LIF and HPLC/ESI/MS. By comparing 
the migration patterns of the peptides, we confirmed that the synthesized peptide had the same electrophoretic behavior as our product. The MS data indicated that the molecular weight of this synthesized peptide matched our reaction product (Table 1). With this confirmation, we can use the synthesized peptide as the standard to perform calibration and quantitation. Quantitation of the product formation can easily been done by

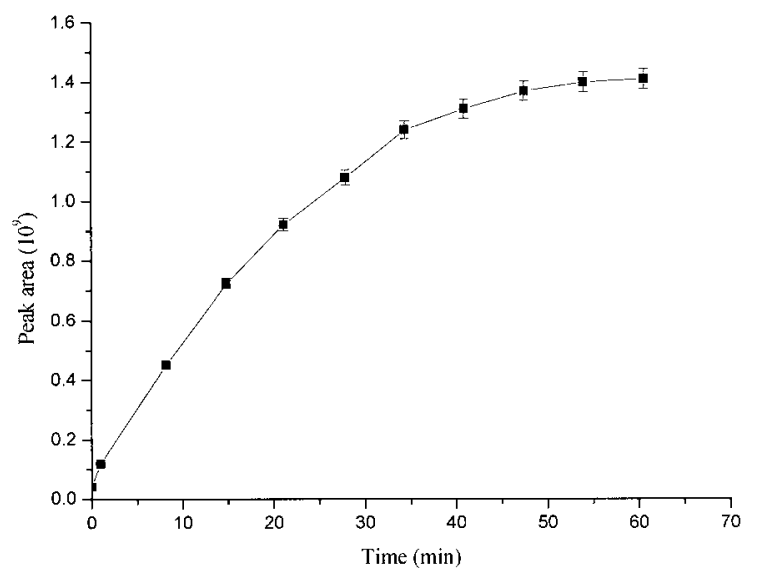

Fig. 2 The time course of a typical SPase enzyme reaction. The reaction conditions: 1) For enzyme reaction, $10 \mu \mathrm{L}$ of substrate and $80 \mu \mathrm{L}$ of $50 \mathrm{mmol} / \mathrm{L}$ Trizma, pH 8.0 were mixed first. Then, $10 \mu \mathrm{L}$ of enzyme was added to the mixture and gently mixed with a vertex to start the reaction. 2) For inhibitor screening, $40 \mu \mathrm{L}$ of inhibitor ( $1 \%$ DMSO for control reaction) in $50 \mathrm{mmol} / \mathrm{L}$ Trizma at $\mathrm{pH} 8.0$ and $5 \mu \mathrm{L}$ of enzyme were mixed for $5 \mathrm{~min}$. Then $5 \mu \mathrm{L}$ of substrate was added to the mixture and gently mixed with a vertex to start the reaction.

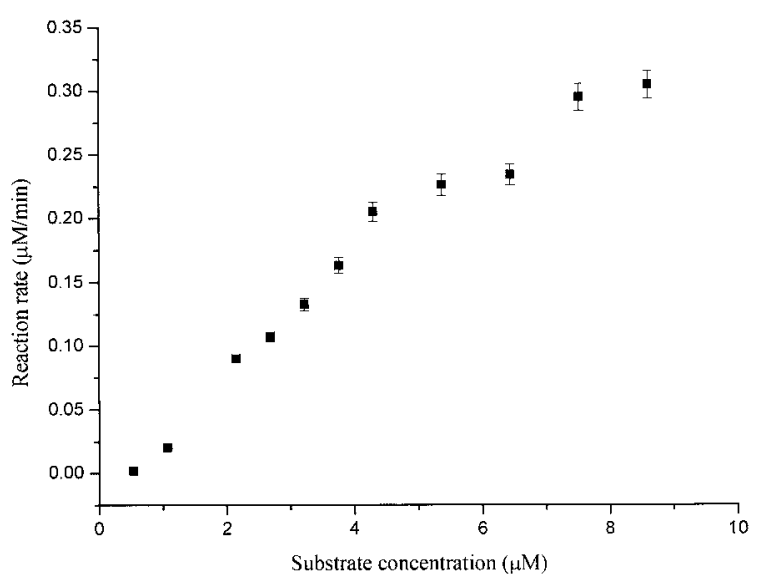

Fig. 3 Initial reaction rates of LEP as different substrate concentrations. The reaction conditions are described in Fig. 2. integrating the product peak. The lower limit of detection $(S / N$ $\geq 3$ ) for the product peak was $1.0 \mathrm{nmol} / \mathrm{L}$. A linear calibration curve based on the peak area of product $(2 \mathrm{kDa})$ was obtained using calibration standards and was used to convert peak area to product concentrations.

\section{Characterization of SPase enzymes}

Since CE consumes only nano-liter volumes of sample, it is feasible to make consecutive injections from a small volume of reaction mixture without affecting the characteristics of the reaction. In the enzyme kinetic study, samples from a reaction mixture of about $100 \mu \mathrm{L}$ were sequentially injected every $3 \mathrm{~min}$. By monitoring the formation and increase of the product peptide fragment $(2 \mathrm{kDa})$ as a function of time, a relationship between the peak area of the $2 \mathrm{kDa}$ product and the time can be plotted, as shown in Fig. 2. This time course can be affected by several parameters, such as substrate/enzyme ratio, specificity of the enzyme, reaction conditions, and the presence of inhibitors. Using the previously described calibration curve, the peak areas on the time course can be converted to concentrations of the product.

The initial reaction rate, which is the slope of the time course as expressed in the concentration of the product, can be measured from the time course. The data points collected at the beginning are almost linear. The slope of this linear curve is the initial rate of the reaction. Thus, by measuring the slopes of the reaction at different concentrations of the substrate, it is possible to obtain a relationship between the initial reaction rates and the initial substrate concentrations (Fig. 3). This plot is equivalent to the plot from the Michaelis-Menten equation:

$$
V=\frac{V_{\max }[\mathrm{S}]}{K_{\mathrm{m}}+[\mathrm{S}]}
$$

where $V_{\max }$ is the maximum velocity of the reaction and $K_{\mathrm{m}}$ is a characteristic parameter of the enzyme. Based on this curve, the $V_{\max }$ and $K_{\mathrm{m}}$ can be calculated by either fitting the curve to the Michaelis-Menten equation or by re-plotting the data using a Lineweaver-Burk plot.

$$
\frac{1}{V}=\frac{k_{\mathrm{m}}}{V_{\max }} \frac{1}{[\mathrm{~S}]}+\frac{1}{V_{\max }}
$$

The $V_{\max }$ and $K_{\mathrm{m}}$ values can be determined from the slopes and the intercepts of these plots. The $V_{\max }$ and $K_{\mathrm{m}}$ values of SPases enzyme from different sources determined from the Lineweaver-Burk plot are listed in Table 2.

\section{Quality control of enzyme/substrate}

This CE/LIF method can be used for quality control of enzyme and/or substrate. For example, this method was successfully applied to compare the activities of SPase from different batches. Some of them have higher activities while others have lower ones. The method has been applied to

\begin{tabular}{|c|c|c|c|c|c|c|}
\hline SPase & Lep & SpsB & Sips & $\mathrm{Spi}^{\mathrm{a}}$ & HOSP & DogSP \\
\hline$K_{\mathrm{m}} / \mu \mathrm{mol} \mathrm{L}-1$ & $16.48 \pm 0.75$ & $19.05 \pm 0.64$ & $3.3 \pm 0.09$ & - & $18.16 \pm 0.73$ & $6.47 \pm 0.11$ \\
\hline$V_{\max } / \mu \mathrm{mol} \mathrm{mg}{ }^{-1} \mathrm{~min}^{-1}$ & $8.9 \pm 0.11$ & $0.27 \pm 0.01$ & $0.014 \pm 0.0003$ & - & $7.5 \pm 0.15$ & $0.11 \pm 0.004 \mu \mathrm{mol} \mathrm{mL}^{-1 t}$ \\
\hline Revised $V_{\max } / \mu \mathrm{mol} \mathrm{mg}{ }^{-1} \mathrm{~min}^{-1}$ & $4.01 \pm 0.16$ & $0.15 \pm 0.06$ & $0.015 \pm 0.0054$ & - & $11.9 \pm 0.43$ & - \\
\hline$V_{\max } / \mu \mathrm{mol} \mathrm{L}-1 \min ^{-1}$ & $0.89 \pm 0.01$ & $1.35 \pm 0.05$ & $0.28 \pm 0.006$ & - & $0.015 \pm 0.0003$ & - \\
\hline
\end{tabular}

Table $2 K_{\mathrm{m}}$ and $V_{\max }$ values of several SPases determined by CE/LIF method

a. The specific enzyme sample has no activity. b. The concentration of DogSP is unknown and the $V_{\max }$ can not be expressed as $\mu \mathrm{mol} \mathrm{mg}^{-1}$ $\min ^{-1}$. - No data available. 
evaluate the enzyme activity of a truncated segment of a SPase that was used for structure determination by crystallization. The result indicated that the truncated portion did retain most of the activity on the other side; this method can thus be used to evaluate the quality of the products.

\section{Screening of enzyme inhibitors}

The CE/LIF method was used to evaluate the potency of different inhibitors towards SPase. For example, the profiles of the time course of enzyme in the presence of five different inhibitors (PG 269594, PG 269596, PG 269599, PG 269601 and PG 269625) are shown in Fig. 4. By comparing with the control, we see that all of them inhibited the reaction to different degrees. PG 269625 has the highest inhibition and PG 269601 has the least inhibitions. The other three compounds, PG 269599, PG 269596 and PG 269594, have moderate inhibitions. Figure 4 also indicates that the effect of different inhibitors can

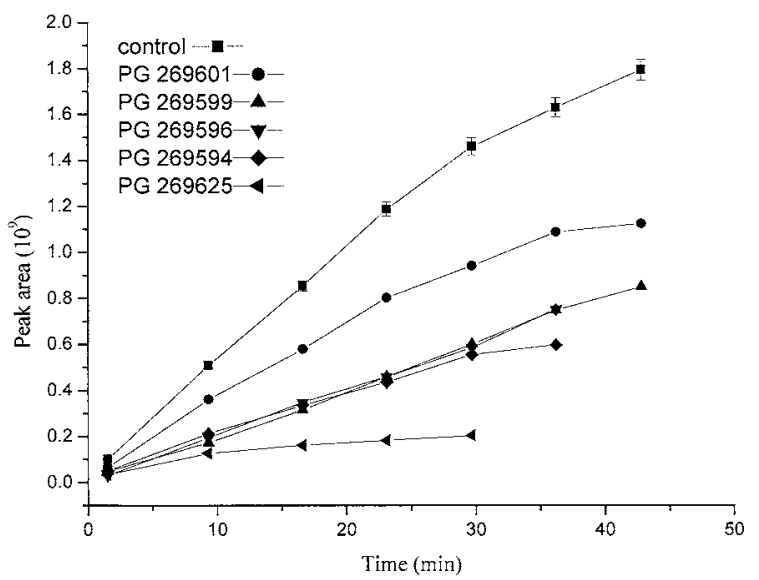

Fig. 4 Comparison of the activity of five $100 \mathrm{mmol} / \mathrm{L}$ inhibitors to SpsB. The reaction conditions are described in Fig. 2. be viewed clearly after $15 \mathrm{~min}$. Thus, by selecting $20 \mathrm{~min}$ as the comparison point, it is possible to quantitatively determine the degree of inhibition for different compounds. When the substrate concentration was increased, the inhibition efficiency was reduced. Furthermore, some of the inhibitors can only inhibit one special kind of SPase, while other inhibitors can inhibit more than one SPase. This is called cross reactivity. Table 3 lists the cross reactivity of several SPase inhibitors.

\section{Effect of DMSO on enzyme activity}

Since $1 \%$ (v/v) DMSO is used to store the inhibitors, in the screening assays, DMSO will be present in the system. A study was conducted to evaluate the effect of DMSO on the activity of SPase enzyme. All conditions remained uniform except the concentration of DMSO varied from 0 to $2 \%$. There is no obvious change of product generated. The results indicated that DMSO had no significant effect on the activity of this enzyme in this range.

\section{Effect of urea concentrations on enzyme activity}

As mentioned above, urea was used in the storage of substrate stock solutions. Therefore, the determination of the reaction rate of the SPase enzyme at difference concentrations of urea was carried out and the results are shown in Fig. 5. The reaction rates were measured for the first $10 \mathrm{~min}$. Urea clearly inhibits the enzyme reaction at certain concentrations. The higher the concentration is, the more the inhibition. SPase enzyme totally lost its activity when the urea concentration was above $3 \mathrm{~mol} / \mathrm{L}$. However, when the urea concentration was below the $0.6 \mathrm{~mol} / \mathrm{L}$, there is slight or no inhibition. The final concentration of urea in substrate working solutions used in this paper was lower than $0.6 \mathrm{~mol} / \mathrm{L}$. Therefore, urea did not affect the enzyme activity significantly.

\section{Comparison of FP and CE/LIF}

Table 4 compares the inhibition results obtained by the two methods. It can be concluded that: (1) both methods agree well for most of the compounds except one, PG 436447; (2) the

Table 3 Cross-reactivity of SPase enzyme inhibitors determined by CE/LIF method

\begin{tabular}{|c|c|c|c|c|c|c|}
\hline Sample name & Purity & $\mathrm{IC} 50^{\mathrm{a}}$ & Substrate $/ \mu \mathrm{mol} \mathrm{L}-1$ & Inhibitor/ $\mu \mathrm{mol} \mathrm{L}^{-1}$ & Inhibition for $\mathrm{SpsB}, \%$ & Inhibition for HOSP, $\%$ \\
\hline \multirow[t]{5}{*}{ MOLPG371162 } & - & 72 & 0.215 & 32 & $21.0 \pm 0.94$ & - \\
\hline & & & & 80 & $49.4 \pm 1.89$ & - \\
\hline & & & & 160 & $68.0 \pm 3.64$ & $66.4 \pm 2.72$ \\
\hline & & & 2.15 & 160 & $39.2 \pm 1.40$ & - \\
\hline & & & & 40 & $15.7 \pm 0.63$ & - \\
\hline \multirow[t]{2}{*}{ DPK PG314527 } & - & 48 & 0.215 & 80 & $71.0 \pm 3.19$ & $86.6 \pm 3.38$ \\
\hline & & & & 160 & $72.0 \pm 3.62$ & - \\
\hline \multirow[t]{4}{*}{ HTS1PG251241 } & 75 & 12.5 & 0.215 & 3.2 & $96.1 \pm 3.64$ & - \\
\hline & & & & 16 & - & $8.0 \pm 0.31$ \\
\hline & & & 2.15 & 3.2 & $12.4 \pm 0.50$ & - \\
\hline & & & & 40 & $60.3 \pm 2.46$ & - \\
\hline \multirow[t]{6}{*}{ HTS2PG258798 } & 61 & 3.12 & 0.215 & 4 & $28.7 \pm 0.97$ & 0 \\
\hline & & & & 16 & $58.2 \pm 2.56$ & 0 \\
\hline & & & & 40 & - & 0 \\
\hline & & & & 80 & - & 0 \\
\hline & & & 2.15 & 40 & $12.3 \pm 0.50$ & - \\
\hline & & & & 160 & $12.3 \pm 0.49$ & - \\
\hline \multirow[t]{4}{*}{ MarkerPG169101 } & $>95$ & 50 & 0.215 & 4 & $41.2 \pm 1.48$ & - \\
\hline & & & & 8 & $55.6 \pm 5.00$ & $21.6 \pm 0.71$ \\
\hline & & & 2.15 & 16 & - & $26.0 \pm 1.07$ \\
\hline & & & & 40 & $10.6 \pm 0.38$ & - \\
\hline
\end{tabular}

a. IC50 was determined by FP method against SpsB enzyme using $0.3 \mu \mathrm{mol} / \mathrm{L}$ substrate. - , No data available. 


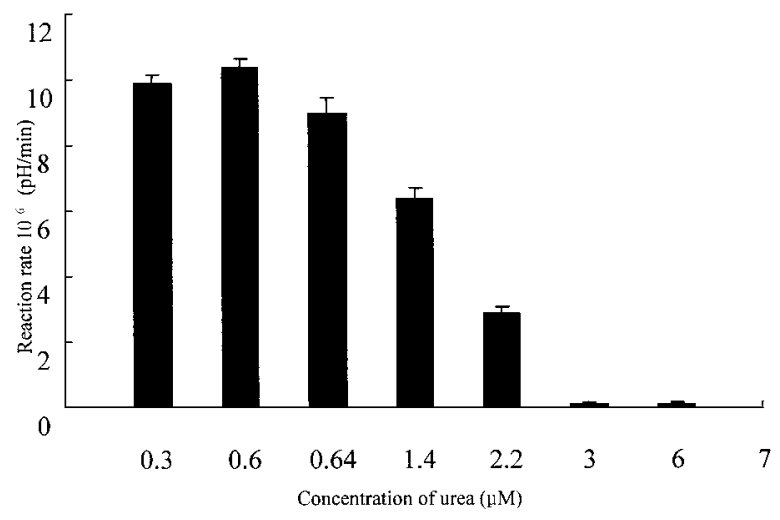

Fig. 5 Effect of urea on the activity of the enzyme. The reaction conditions: $5 \mu \mathrm{L}$ of the substrate $(1.7 \mathrm{mg} / \mathrm{mL})$ was mixed with $40 \mu \mathrm{L}$ of different concentrations of urea in $50 \mathrm{mmol} / \mathrm{L}$ Trizma at $\mathrm{pH}$ 8.0. Then, $5 \mu \mathrm{L}$ of LEP $(0.001 \mathrm{mg} / \mathrm{mL})$ was added to start.

CE/LIF method can give more accurate information while FP method is simply on or off. Therefore, it can be concluded based on the above results that the FP methods are more suited for the initial HTS assay while the CE/LIF is more suited for the second tier assay where more quantitive information is needed. With the recent development in multiplexed CE system, it will be possible for the CE/LIF method to be used as the initial screening method as well.

\section{Conclusions}

A robust method of CZE combined with LIF was developed and applied for the characterization of several SPase enzymes and the evaluation of the potency of several inhibitors. The effects of various reaction conditions, such as $\mathrm{pH}$, DMSO, and urea concentration, on the enzyme reaction were also studied. In addition, this CE/LIF method was also applied to determination of the enzyme activity, quality control of the substrate and/or enzymes, comparisons of enzyme from different sources or batches, and cross-reactivity of inhibitors to different enzymes. This method has several advantages over the fluorescence polarization (FP) method previously used for high throughput screening (HTS) assays by delivering faster, more sensitive, more quantitative, and more reliable results. It was proved that this method could be a potential substitution for certain compounds used for future high throughput screening assays.

\section{Acknowledgements}

The authors would like also to thank Drs. L. Dhu and Mr. C. Morris for their support of this project.

\section{References}

1. A. J. M. Dricssen, P. Fekkes, and J. P. W. Van der Wolk, Curr. Opin. Microbiol., 1998, 1, 216.

2. A. Economou, Mol. Microbiol., 1998, 27, 511.

3. W. Wickner, A. J. M. Dricssen, and F. U. Hartl, Annu. Rev. Biochem., 1991, 60, 101.
Table 4 Comparison between FP and CE/LIF methods for inhibition study

\begin{tabular}{ccc}
\hline \multirow{2}{*}{ Compound } & \multicolumn{2}{c}{ Inhibition, \% } \\
\cline { 2 - 3 } & CE/LIF method & FP method \\
\hline PG450785 & None & None \\
PG436448 & $97.6 \pm 3.16$ & Complete \\
PG436447 & $79.4 \pm 3.74$ & None \\
PG436204 & None & None \\
PG341174 & $90.0 \pm 3.06$ & Complete \\
PG341173 & $99.8 \pm 2.14$ & Complete \\
PG423987 & $70.0 \pm 2.52$ & Complete \\
PG421228 & $98.9 \pm 3.26$ & Complete \\
PG421227 & $80.1 \pm 3.52$ & Complete \\
PG437719 & None & None \\
\hline
\end{tabular}

4. W. R. Tschantz and R. E. Dalbey, "Methods in Enzymology", 1994, Academic Press, Inc.

5. M. Takahara, D. W. Hibler, P. J. Barr, and J. A. Gerlt, J. Biol. Chem., 1985, 260, 2670.

6. S. Chatterjee, D. Suciu, R. E. Dalbey, P. C. Kahn, and M. Inouye, J. Mol. Biol., 1995, 245, 311.

7. M. Paetzel, R. E. Dalbey, and N. C. J. Strynadka, Pharmacol. Ther., 2002, 87, 27.

8. L. J. Ma, X. Y. Gong, and E. S. Yeung, Anal. Chem., 2000, 72,3383 .

9. G. Bruton, A. Huxley, P. O’Hanlon, B. Orlek, D. Eggleston, J. Humphries, S. Readshaw, A. West, S. Ashman, M. Brown, K. Moore, A. Pope, K. O'Dwyer, and L. Wang, Eur. J. Med. Chem., 2003, 38, 351.

10. F, M. Sung and R. E. Dalbey, J. Biol. Chem., 1992, 267, 13154.

11. J. L. Carlos, P. A. Klenotic, M. Paetzel, and N. C. Strynadka, Biochemistry, 2000, 39, 7276.

12. C. Van Valkenburgh, X. Chen, C. Mullins, H. Fang, and N. Green, J. Biol. Chem., 1999, 274, 11519.

13. P. A. Klenotic, J. L. Carlos, J. C. Samuelson, T. A. Schuenemann, and W. R. Tschantz, J. Biol. Chem., 2000, 275, 6490.

14. W. R. Tschantz, M. Sung, V. M. Delgado-Partin, and R. E. Dalbey, J. Biol. Chem., 1993, 268, 27349.

15. W. R. Tschantz, M. Paztel, G. Cao, D. Suciu, M. Inouye, and R. E. Dalbey, Biochemistry, 1995, 43, 3935.

16. R. L. Stein, M. D. F. S. Barbosa, and R. Bruckner, Biochemistry, 2000, 39, 7973.

17. A. E. Allsop, G. Brooks, G. Bruton, S. Coulton, P. D. Edwards, I. K. Hatton, A. C. Kaura, S. D. Mclean, N. D. Pearson, T. C. Smale, and R. Southgate, Bioorg. Med. Lett., 1995, 5, 443 .

18. L. M. Levine, M. L. Michener, M. V. Toth, and B. C. Holwerda, Anal. Biochem., 1997, 247, 83.

19. I. K. Dey, P. H. Ray, and P. Novak, J. Biol. Chem., 1990, 265, 20069.

20. M. C. Roach, P. Gozel, and R. N. Zare, J. Chromatogr., 1988, 426, 129.

21. H. T. Chang and E. S. Yeung, Anal. Chem., 1995, 67, 1079.

22. W. T. Lowther and B. M. Dunn, Lett. Peptide Sci., 1994, 1, 89.

23. J. Tu, L. N. Anderson, J. Dai, and K. Peters, $J$. Chromatogr., B, 2003, 789, 323. 